\title{
Pecking Order Theory versus Trade-Off Theory: are service SMEs' capital structure decisions different?
}

\author{
Zélia Silva Serrasqueiro • Manuel Rocha Armada • \\ Paulo Maçãs Nunes
}

\begin{abstract}
This paper seeks to analyse if the capital structure decisions of service small and medium-sized enterprises (SMEs) are different from those of other types of firm. To do so, we consider four research samples: (i) 610 service SMEs; (ii) 126 service large firms; (iii) 679 manufacturing and construction SMEs; and (iv) 132 manufacturing and construction large firms. Using the two-step estimation method, the empirical evidence obtained in this study shows that the capital structure decisions of service SMEs are different from those of other types of firm. Service SMEs' capital structure decisions are closer to the assumptions of Pecking Order Theory and further removed from those of Trade-Off Theory compared with the case of other types of firm.
\end{abstract}

Keywords Other firms · Pecking Order Theory - Service SMEs - Trade-Off Theory $\cdot$ Two-step estimation method

JEL Classification G32 $\cdot$ L80

Z. S. Serrasqueiro · P. M. Nunes

Management and Economics Department, Beira Interior University, Covilhã, Portugal

Z. S. Serrasqueiro · P. M. Nunes

CEFAGE Research Center, Évora University, Évora, Portugal

Z. S. Serrasqueiro $(\square)$

Faculdade de Ciências Sociais e Humanas, Universidade da Beira Interior,

Estrada do Sineiro, Polo IV, Ernesto Cruz, 6200-209 Covilhã, Portugal

e-mail: zelia@ubi.pt

M. R. Armada

Management and Economics School, Minho University, Braga, Portugal

M. R. Armada

NEGE Research Center, Minho University, Braga, Portugal 


\section{Pecking Order Theory Versus Trade-Off Theory: Are Service SMEs' \\ Capital Structure Decisions Different?}

\section{Introduction}

In the context of firms' financing decisions, after the important contributions by Modigliani and Miller (1958, 1963), various studies were devoted to investigating what the main determinants of firms' capital structure were. In this connection, two theories are particularly relevant in explaining firms' capital structure: i) Trade-Off Theory (Kraus and Litzenberger, 1973; Scott, 1977; Kim, 1978); and ii) Pecking Order Theory (Myers, 1984; Myers and Majluf, 1984). According to Trade-Off Theory, firms seek to achieve the target debt ratio that corresponds to the point where the marginal benefits equal the marginal costs of debt. According to Pecking Order Theory, variations in debt do not are not motivated by the wish to achieve the target debt ratio, but are the consequence of the accumulated funding needs that are not covered by internal finance, and in this situation firms prefer to turn to debt rather than external equity. According to these two main theories, capital structure decisions are influenced by several firm characteristics, namely: profitability, size, age, growth opportunities, risk, asset structure, non-debt tax shields, and others. Pecking Order and Trade-off theories do not converge regarding the influence of these determinants on capital structure decisions.

Small and medium-sized enterprises (SMEs), mainly smaller and younger firms with growth opportunities that are associated with high risk, are known to have difficulty in obtaining external finance. Size and tangible assets can be particularly important for SMEs with insufficient internal finance to be able to obtain debt on more advantageous terms to fund the multiple investment opportunities. 
Service SMEs have peculiar characteristics that may justify the differences in their capital structure decisions in comparison to those taken by other types of firm. Indeed, smaller size together with lower level of tangible assets may aggravate the problems of information asymmetry between service SME owners/managers and creditors, leading creditors to impose particularly adverse conditions for these firms to obtain debt.

The service industry sector is especially important in the European economy in general, and in peripheral economies such as Portugal in particular. In this context, the service industry sector is especially important for economic and employment growth in Portugal. SMEs account for $99.68 \%$ of all firms in Portugal (INE, 2010). Among Portuguese SMEs, service SMEs are particularly important. Between 2000 and 2005, with respect to SMEs in the service industry, growth in the number of firms was found to be the $10.1 \%$, employment growth was $8.6 \%$, and growth of business turnover was 7.3\%. In comparison, concerning SMEs in manufacturing industry, growth in the number of firms was found to be $4.5 \%$, employment fell by $0.2 \%$, and business turnover fell by $0.3 \%$.

Given the considerable importance of service SMEs in the Portuguese economy, it is particularly relevant to study how information asymmetry between these firms and creditors, influences their capital structure decisions, making service SMEs a special case regarding financing strategies, compared to what occurs in other types of firms. Therefore, this paper seeks to analyse if the capital structure decisions of service small and medium-sized enterprises (SMEs) are different from those of other types of firm

To reach the goal of this study, we use four research samples: i) 610 service SMEs; ii) 126 large service firms; iii) 679 SMEs in manufacturing and construction industries; and $i v$ ) 132 large firms in manufacturing and construction industries. In this way, we compare the results obtained for service SMEs with those for larger firms with higher 
level of tangible assets to analyse the possible influence of problems of information asymmetry in relationships between service SME owners/managers and creditors on the financing decisions of service SMEs, compared to what occurs in other types of firm.

Methodologically, so as to avoid possible result bias due to the matter of survival, we use the two-step estimation method proposed by Heckman (1979). In the first step, we use probit regressions, considering all service SMEs and other types of firm. In the second step, after calculating the inverse Mill's ratio, and including it in the regressions, considering surviving service SMEs and other surviving firms, we estimate the regressions with respect to the applicability of Pecking Order Theory and Trade-Off Theory to the capital structure decisions of service SMEs and other types of firm.

This paper has various original contributions regarding the state-of-the-art of the literature on SME capital structure in general, and the capital structure of service SMEs in particular. Firstly, it is pioneering in studying specifically the applicability of representative models of Pecking Order Theory and Trade-Off Theory to the capital structure decisions of service SMEs. Secondly, it is pioneering in comparing the applicability of representative models of Pecking Order Theory and Trade-Off Theory between the situation of service SMEs and that of other types of firm, namely large service firms, manufacturing and construction SMEs and large manufacturing and construction firms. Thirdly, the study is pioneering in applying the two-step estimation method to the capital structure decisions of service SMEs, and comparing them with the capital structure decisions of other types of firm.

The multiple empirical evidence presented in this paper allow us to draw a particularly important conclusion for managers, practitioners and academics: the capital structure decisions of service SMEs are considerably different from those of other types of firm, such as large service firms, and SMEs and large firms in manufacturing and 
construction industries. Decisive for this result could be the combination of smaller size and lower level of tangible assets that particularly affect service SMEs, compared to other types of firm.

After this introduction, this paper has the following structure: i) Section 2. Methodology and Research Hypotheses, presents the models to estimate, the variables used and corresponding measures, the estimation method and research hypotheses; $i$ ) Section 3. Database and Descriptive Statistics, presents the database used and the descriptive statistics of the variables used in the study; iii) Section 4. Results, presents the empirical evidence obtained in the study; $i v$ ) Section 5. Discussion of the Results, goes on to discuss the empirical evidence obtained; and $v$ ) finally, Section 6. Conclusions and Implications, presents the main conclusions and implications of the study.

\section{Methodology and Research Hypotheses}

In this section we present the models used to test the applicability of Pecking Order and Trade-Off theories to the capital structure decisions of service SMEs and other types of firm. Initially, we present the models to estimate together with the variables used and their corresponding measures, and after this we present the research hypotheses.

\subsection{Pecking Order Theory}

\section{Relationship between Financial Deficit and Debt - POT Model I}

Firstly, to test Pecking Order Theory, we use the model proposed by Shyam-Sunder and Myers (1999). This model consists of testing a regression between financial deficit and variations in debt. 
To solve the problem of possible bias in the results due to the survival issue, we use the two-step estimation method proposed by Heckman (1979). In the first step, we estimate a probit regression, taking all surviving and non-surviving firms, considering all explanatory variables corresponding to the regressions to estimate in the second step. Therefore, the regressions to estimate can be presented as follows:

$$
\operatorname{Pr}\left(\delta_{i, t}=1\right)=\tau_{0}+\tau F D_{i, t}+d_{t}+z_{i, t},
$$

where: $\operatorname{Pr}\left(\delta_{i, t}=1\right)$ is survival probability; $\tau$ is the parameter to measure the impact of financial deficit on survival probability, $F D_{i, t}$ is financial deficit, $d_{t}$ represents temporal dummies, and $z_{i, t}$ is the error term.

In the second step of estimation, we consider the inverse Mill's ratio ${ }^{2}$, as an explanatory variable for service SMEs and other types of firm. According to Pecking Order Theory, variations in debt occur exclusively as a function of firms' financing needs. We extend the model proposed by Shyam-Sunder and Myers (1999), including the inverse Mill's ratio in regressions as an explanatory variable, so as to solve the problem of possible result bias as a consequence of the survival issue. Therefore, the regressions to estimate can be presented as follows:

$$
\Delta D_{i, t}=\beta_{0}+B F D_{i, t}+\gamma_{\lambda} \lambda_{i, t}+d_{t}+\varepsilon_{i, t}
$$

where $\Delta D_{i, t}$ is the difference between debt in the current period and debt in the previous period, $B$ is the parameter to measure the impact of financial deficit on debt variations,

\footnotetext{
2 The inverse Mill's ratio is the ratio between cumulative density function and the density function. The designation of inverse Mill's ratio is due to the fact that Mill's ratio considers the inverse of Hazard ratio (also known as force of mortality). For a detailed description of calculation of the inverse Mill's ratio, see Heckman (1979).
} 
$\lambda_{i, t}$ is the inverse Mill's ratio, $d_{t}$ represents temporal dummies, and $\varepsilon_{i, t}$ is the error that is assumed to have normal distribution.

To estimate equation (2), we turn to OLS regressions for two fundamental reasons: i) the non-existence of the lagged dependent variable in the relationship forecast by equation (2) makes use of dynamic estimators impossible; and ii) since the dependent variable is in first differences, non-observable individual effects $\left(v_{i}\right)$ become irrelevant, and it is no impossible to estimate the relationship forecast in equation (2) with panel models considering random or fixed non-observable individual effects.

Given that heteroskedasticity is normally a relevant phenomenon in empirical studies that use cross-section data, standard deviations of the parameters are estimated according to the White estimator. This estimator allows us to obtain standard deviations of estimated parameters consistent with the possible existence of heteroskedasticity.

\section{Determinants of Debt - POT Model II}

Following other studies (Michaellas et al., 1999; Aybar et al., 2004³ ; López-Gracia and Sánchez-Andújar, 2007; López-Gracia and Sogorb-Mira, 2008), we test the Pecking Order Theory, on the basis of a second regression model, considering the determinants of debt according to what is predicted by Pecking Order Theory: $i$ ) cash flow; ii) age; and iii) interaction between cash flow and growth opportunities.

As in Model I, in the first step we estimate probit regressions in order to estimate the inverse Mill's ratio. The regressions to estimate can be presented as follows:

$$
\begin{aligned}
& \operatorname{Pr}\left(\delta_{i, t}=1\right)=\tau_{0}+\tau_{1} C F_{i, t}+\tau_{2} A G E_{i, t}+\tau_{3} H G O L C F_{i, t}+\tau_{4} L G O H H C F_{i, t}+ \\
& +d_{t}+z_{i, t}
\end{aligned}
$$

\footnotetext{
${ }^{3}$ Aybar Arias, C., Casino Martínez, A. and López Gracia, J. (2004). Efectos Financieros y Estratégicos sobre la Estructura de Capital de la Pequeña y Mediana Empresa. Moneda y Crédito, 58, 71-98.
} 
in which: $C F_{i, t}$ corresponds to cash flow, given by the ratio of earnings after interest and taxes plus depreciation to total assets; $A G E_{i, t}$, is age, given by the number of years the firm has been in existence; $H G O L C F_{i, t}$, are the growth opportunities of firms (i), at a given moment $(\mathrm{t})$, corresponding to situations of high growth opportunities and low cash flow; $\mathrm{LGOHCF}_{i, t}$, are the growth opportunities of firm (i), at a given moment (t), corresponding to situations of low growth opportunities and high cash flow.

To calculate $H G O L C F_{i, t}$ we consider initially a dummy variable with the value of 1 corresponding to firms that, at a given moment, have simultaneously growth opportunities above the median of growth opportunities of the total sample and cash flow under the median of cash flow of the total sample; and the value of 0 in the remaining situations. To calculate $L G O H C F_{i, t}$ we consider, initially, a dummy variable with the value of 1 when firms, at a given time, have simultaneously growth opportunities under the median of growth opportunities of the total sample and cash flow above the median of cash flow of the total sample; and the value of 0 in the remaining situations. Finally, to calculate the variables $H G O L C F_{i, t}$ and $L G O H C F_{i, t}$, we multiply the previously calculated dummy variables by sales growth (considered as a measure of growth opportunities).

In the second step, to estimate the relationships forecast by Pecking Order Theory between determinants and debt, for service SMEs and other types of firm, we use static panel models. The regressions to estimate can be presented as follows:

$$
\begin{aligned}
& D_{i, t}=\beta_{0}+\beta_{1} C F_{i, t}+\beta_{2} A G E_{i, t}+\beta_{3} H G O L C F_{i, t}+\beta_{4} L_{G O H C F}+ \\
& +\gamma_{\lambda} \lambda_{i, t}+u_{i}+d_{t}+\varepsilon_{i, t}
\end{aligned},
$$


in which: $D_{i, t}$ corresponds to debt, given by the ratio of total liabilities to total assets and $u_{i}$ are firms' specific factors that are not directly observable from debt determinants.

We use the LM test in order to verify if non-observable individual effects $\left(u_{i}\right)$ are relevant in explaining debt. The null hypothesis indicates the irrelevance of nonobservable individual effects, against the alternative hypothesis of relevance of nonobservable individual effects. In the case of rejecting the null hypothesis, due to the relevance of non-observable individual effects in explaining debt, an OLS regression is not the most appropriate way to estimate the relationships between determinants and debt. If non-observable individual effects are relevant in explaining debt, we also use the Hausman test to check whether non-observable individual effects are correlated with the independent variables. The null hypothesis indicates the non-existence of correlation between non-observable individual effects and the independent variables, against the alternative hypothesis that non-observable individual effects are correlated with the dependent variable. By not rejecting the null hypothesis, non-observable individual effects are not correlated with the independent variables, and so it makes no difference estimating relationships between determinants and debt with a random or fixed effect panel model. In the case of rejecting the null hypothesis, there is correlation between non-observable individual effects and the independent variables, and so the relationships between determinants and debt should be estimated using a fixed effect model.

This paper presents the results of the LM and Hausman tests for the different types of firms considered, and the most suitable model for estimating results with respect to to relationships between determinants and debt for the different types of firms considered. 


\section{Research Hypothesis}

According to Pecking Order Theory, variations in debt occur exclusively as a function of firms' financing needs, i.e., debt variations are a function of the financial deficit found at a given time (Shyam-Sunder and Myers, 1999). In addition, according to Pecking Order Theory, we can also expect that: $i$ ) firms with greater cash flow resort less to debt (Myers, 1984; Myers and Majluf, 1984); ii) older firms resort less to debt (Diamond, 1989; Ang, 1991); iii) firms with greater growth opportunities and low cash flow resort more to debt (Myers, 1984); and iv) firms with low growth opportunities and high cash flow resort less to debt (Myers, 1984).

In the SME context, various studies point toward firms preferring to fund themselves through retained profits, or else through recourse to the savings of family or friends (Pettit and Singer, 1985; Ang 1992; Scherr and Hulburt 2001; López-Gracia and Sánchez-Andújar, 2008; Ramalho and Silva 2009). SME preference for retained profits is related to the particular difficulties faced by SMEs in obtaining external finance, due to their greater likelihood of bankruptcy (Pettit and Singer, 1985; Ang, 1991). Indeed, Franco and Haase (2010) conclude that financing restrictions are one of the main problems affecting these firms' survival in their operating markets.

Cruz-Ros et al. (2010) conclude that intangible assets are particularly relevant for increased performance in service firms. However, the authors conclude that service firm activities based on intangible assets may contribute to these firms having greater difficulty in obtaining debt. According to Cressy and Olofsson (1997) and Abor (2007), for SMEs with higher level of tangible assets it is easier to obtain debt than for SMEs whose activities are based predominantly on intangible assets. For Cressy and Olofsson (1997), greater intangibility of assets in service firms in general, and service SMEs in particular, contributes decisively to these firms to have greater difficulty in obtaining 
debt than may be the case of firms belonging to other sectors of activity where tangible assets are more important.

Service SMEs may be particularly dependent on internal finance to fund their multiple growth opportunities. Smaller size, associated with the importance of intangible activities in these firms' activities, and consequently lower capacity in providing tangible assets security on debt may aggravate the problems of information asymmetry. Therefore, creditors may hinder service SMEs' access to debt. When internal finance is insufficient, service SMEs' particular difficulty in obtaining external funding may prevent these firms from taking advantage of the multiple opportunities available to this type of firm. The majority of service SMEs do not fulfill the requirements to be listed in the stock market, and when firms have little tradition of using venture capital, as occurs in peripheral economies like Portugal, SMEs are restrained in using alternative funding sources to internal finance.

Based on the above arguments, we can expect that: $i$ ) the impact of financial deficit on variations of debt is of a greater magnitude for service SMEs than for other types of firm; ii) as a function of cash flow, age, low growth opportunities and high cash flow, service SMEs turn less to debt than other types of firms,; and iii) in situations of high growth opportunities and low cash flow, service SMEs turn less to debt than other types of firm. Therefore, we formulate the following research hypothesis:

H1: The capital structure decisions of service SMEs are closer to what is forecast by Pecking Order Theory than the capital structure decisions of other types of firm. 


\subsection{Trade-Off Theory}

Adjustment of Actual Level of Debt toward Target Debt Ratio and Debt Determinants

We present the partial adjustment that allows us to test the degree of adjustment of actual debt toward target debt ratio, and the relationships between debt and determinants forecast by Trade-Off Theory. Firstly, we estimate probit regressions, considering as explanatory variables the determinants of debt according to Trade-Off Theory. The regressions to estimate can be presented as follows:

$$
\begin{aligned}
& \operatorname{Pr}\left(\delta_{i, t}=1\right)=\tau_{0}+\tau_{1} \text { PROF }_{i, t}+\tau_{2} \operatorname{SIZE}_{i, t}+\tau_{3} \text { TANG }_{i, t}+\tau_{4} G O_{i, t}+ \\
& +\tau_{5} \text { NDTS }_{i, t}+\tau_{6} \text { ETR }_{i, t}+\tau_{7} E V O L+D_{S}+d_{t}+z_{i, t}
\end{aligned},
$$

in which: profitability $\left(P R O F_{i, t}\right)$ is given by the ratio of earnings before interest and taxes to total assets; size $\left(S I Z E_{i, t}\right)$ is the natural logarithm of total assets; asset tangibility $\left(T A N G_{i, t}\right)$ is the ratio of tangible assets to total assets; growth opportunities $\left(G O_{i, t}\right)$ is the growth of total assets; non-debt tax shields $\left(N D T S_{i, t}\right)$ is the ratio of depreciations and amortizations to total assets; effective tax rate $\left(E T R_{i, t}\right)$ is the ratio of actual income tax paid to net taxable income before taxes; level of risk $\left(E V O L_{i, t}\right)$ is the absolute value of the first difference of percentage change of earnings before interest, taxes and depreciation.

In the second step of estimation, we estimate the adjustment of the actual debt level in service SMEs and other types of firm, toward respective target debt ratios, as well as the relationships between determinants and debt forecast by Trade-Off Theory, using the GMM system (1998) dynamic estimator. To do so, just as López-Gracia and 
Sánchez-Andujar (2007) and López-Gracia and Sogorb-Mira (2008), we use the partial adjustment model, which is given by:

$D_{i, t}-D_{i, t-1}=\alpha\left(D_{i, t} *-D_{i, t-1}\right)$,

in which: $D_{i, t-1}$ is the debt of firm $i$ in the period $t-1 ; D_{i, t} *$ is the target debt ratio of firm $i$ in period $t$, and $\alpha$ is the speed of adjustment of actual level of debt toward target debt ratio.

To estimate the above equation it is necessary to find the target debt ratio that is not directly observable. In this study we consider just as López-Gracia and SánchezAndújar (2007) and López-Gracia and Sogorb-Mira (2008), that target debt ratio depends on firms' specific characteristics. Therefore, firms' target debt ratio is given by:

$D_{i, t} *=\sum_{K=1}^{n} \varphi_{K} Z_{k, i, t}+\gamma_{\lambda} \lambda_{i, t}+D_{S}+d_{t}+u_{i}+v_{i, t}$

in which $Z_{K, i, t}$ is the determinant $k$ of the debt of firm $i$ at time $t, \varphi_{K}$ are the coefficients of each debt determinant and $v_{i, t}$ is the error term.

Substituting (7) in (6) and regrouping the terms, we have:

$D_{i, t}=\lambda_{0} D_{i, t-1}+\sum_{K=1}^{n} \beta_{K} Z_{k, i, t}+\eta_{i}+\theta_{t}+\varepsilon_{i, t}$

in which: $\lambda_{0}=(1-\alpha), \beta_{K}=\alpha \varphi_{K}, \eta_{i}=\alpha u_{i}, \theta_{t}=\alpha d_{t}$, and $\varepsilon_{i, t}=\alpha v_{i, t}$.

To estimate the equation (8) on the basis of traditional panel methods, considering fixed or random individual effects, we obtain biased and inconsistent estimates of the parameters, given that, asides from the existence of correlation between $\eta_{i}$ and $D_{i, t-1}$, there is also correlation between $\varepsilon_{i, t}$ and $D_{i, t-1}$, i.e., firms' non-observable individual effects and the error are correlated with the lagged debt. In addition, use of dynamic 
estimators rather than use of traditional panel methods has the following extra advantages: $i$ ) greater control of endogeneity; $i$ ) greater control of possible collinearity between explanatory variables; and iii) greater effectiveness in controlling effects caused by the absence of relevant explanatory variables for the results.

This study uses the Generalized Moments Method - GMM system (1998) estimator by Blundell and Bond (1998) to estimate the model of partial adjustment. Blundell and Bond (1998) conclude that when the dependent variable is persistent, the GMM system (1998) estimator is more robust than the Generalized Moments Method - GMM (1991) estimator $^{4}$. Blundell and Bond (1998) extend the GMM (1991) estimator, considering a system of variables at level and in first differences. For the variables at level the instruments are presented in first differences, and for the variables in first differences the instruments are presented at level.

Nevertheless, the GMM system (1998) estimator can only be considered valid if: $i$ ) the restrictions, a consequence of use of the instruments, are valid; and $i i$ ) there is no second-order autocorrelation.

To test the validity of the restrictions, we use the Hansen test. The null hypothesis indicates that the restrictions, imposed by use of the instruments, are valid. By rejecting the null hypothesis, we conclude that the restrictions are not valid, and so the results are not robust. We test for the existence of first and second-order autocorrelation. The null hypothesis is that there is no autocorrelation. Rejecting the null hypothesis of nonexistence of second-order autocorrelation, we conclude that the results are not robust. For the results of the GMM system (1998) estimator to be considered robust, the

\footnotetext{
${ }^{4}$ In this study, we find persistence of debt for service SMEs and other types of firms. The correlation coefficient of present debt and previous debt is 0.81991 in service SMEs, 0.84513 in large service firms, 0.82737 in other SMEs, and 0.85616 in other large firms. Therefore, it is clearly advisable to use the GMM system (1998) estimator, rather than the GMM (1991) estimator.
} 
restrictions imposed by use of the instruments have to be valid and there can be no second-order autocorrelation.

To test the robustness of the empirical evidence obtained, we use the LSDVC (2005) estimator, proposed by Bruno (2005). The LSDVC (2005) estimator is appropriate in situations without a great number of observations. If the number of crosssections is below 30, it is recommendable to use the LSDVC (2005) estimator to test the robustness of the results obtained with the GMM system (1998) estimator. The results are presented in an appendix.

\section{Research Hypothesis}

According to Trade-Off Theory, firms adjust the actual debt level toward a target debt ratio (Lev and Pekelman, 1975; Ang, 1976; Taggart, 1977; Jalilvand and Harris, 1984). Lower transaction costs borne by firms in obtaining debt will correspond to greater adjustment of the actual debt level toward the target debt ratio. Also according to TradeOff Theory, we can expect that: $i$ ) firms with level of profitability turn more to debt (Kraus and Litzenberger, 1973; Scott, 1977; Kim, 1978); ii) larger firms turn more to debt (Rajan and Zingales, 1995); iii) firms with more tangible assets turn more to debt (Myers, 1977; Scott, 1977; Myers and Majluf, 1984; Harris and Raviv, 1991); iv) firms with greater growth opportunities turn less to debt (Jensen and Meckling, 1976; Myers, 1977; Stulz, 1990; McConnell and Servaes, 1995; Barclay et al., 2006); v) firms with greater non-debt tax shields turn less to debt (DeAngelo and Masulis, 1980); vi) firms with higher effective tax rates turn more to debt (Haugen and Senbet, 1986; Scott, 1976; DeAngelo and Masulis, 1980); and vii) firms with greater risk turn less to debt (Bradley et al., 1984; Mackie-Mason, 1990). 
Service SMEs can be particularly affected by problems of information asymmetry in the relationships between owners/managers and creditors. Service SME special characteristics, such as higher levels of intangible assets, and consequently lower level of tangible assets may lead lenders to make credit difficult. Furthermore, SMEs' smaller size and consequently higher level of risk and probability of bankruptcy may lead creditors to associate this type of firm with high risk, and consequently make terms of credit difficult.

Small firms are known to have a high business risk associated with their activities, and high bankruptcy costs, which may imply high transaction costs in obtaining debt (Revest and Sapio, 2010).

Due to the high information asymmetry in relationships between the owners/managers of service SMEs and creditors, these firms may find it particularly difficult to obtain debt, compared to other types of firms. Indeed, firstly the greater size of large service firms may contribute to reducing the information asymmetry implicit in the relationships established with creditors, contributing to debt being obtained on more advantageous terms. Secondly, in general, the higher level of tangible assets in firms in other industries, namely those belonging to the manufacturing and construction industries implies that their risk default become lower. Therefore, it is easier for firms belonging to the manufacturing and construction industries to obtain debt. For example, large firms in the manufacturing and construction industries might find much easier to obtain debt, due to their greater size together with higher level of tangible assets, than service SMEs.

Elston and Audretsch (2009) state that recourse to debt on particularly adverse terms imposed by creditors can harm firm's profitability, therefore contributing to diminished 
probability of survival. Therefore, firms that face particularly harsh credit terms may choose debt only in cases of extreme fund needs.

The greater information asymmetry associated with relationships between service SME owners/managers and creditors, and consequently higher transaction costs for this type of firm, may lead service SMEs to consider the reaching of the target debt ratio as a merely secondary objective.

Firms with greater size (Pettit and Singer, 1985; Ang, 1991), and/or with higher level of tangible assets (Holmes and Kent, 1991; Abor, 2007), consequently with less problems of information asymmetry, may have lower transaction costs associated with debt. Consequently, greater firms and firms with greater level of tangible assets can choose strategies more oriented to the long-term, i.e., more directed toward increasing firm value rather than using external finance only to cover insufficiencies of internal finance.

On the basis of the above exposition, we can expect that the financing behavior of service SMEs is further removed from the assumptions of Trade-Off Theory as other types of firm, and so we can expect that: i) service SMEs have a lower speed of adjustment of the actual level of debt toward target debt ratio than do the other types of firm; ii) service SMEs resort less to debt as a function of profitability, size, tangible assets, and effective tax rate than do the other types of firm; and iii) service SMEs resort more to debt as a function of growth opportunities, non-debt tax shields and risk, compared to the other types of firm. Based on the above, we formulate the following research hypothesis:

H2: The capital structure decisions of service SMEs are further removed from the forecasts of Trade-Off Theory than do the capital structure decisions of other types of firms. 


\section{Database and Descriptive Statistics}

\subsection{Database}

This study uses the SABI (Analysis System of Iberian Balance Sheets) database, supplied by Bureau van Dijk for the period between 1999 and 2006. The selection of firms by industry sector was done in accordance with the NACE (Classification of Economic Activities in the European Union) classification ${ }^{5}$. We select SMEs based on the European Union recommendation L124/36 (2003/361/CE). According to this recommendation, a firm is considered an SME when it meets two of the following criteria: i) fewer than 250 employees; ii) total assets under 43 million euros; and iii) turnover under 50 million euros. Firms that do not meet these criteria are considered large firms.

To solve the problem of possible result bias due to the matter of the survival effect, and also seeking to have a more representative sample of the Portuguese firms, we consider three types of firm: $i$ ) firms belonging to the market for the whole period of analysis (1999-2006); $i$ ) firms entering the market during the period of analysis (19992006); and iii) firms leaving the market during the period of analysis (1999-2006).

Given the use of dynamic panel estimators, there are restrictions in including firms that are in the sample for a very limited number of years. According to Arellano and Bond (1991), firms must be present in the database for at least four consecutive years to be considered in the econometric analysis and in the second-order autocorrelation tests

\footnotetext{
5 Services include: Real Estate Activities; Renting of Machinery and Equipment without Operator and Personal and Household Goods; Computer and Related Activities; and Other Business Activities. Other firms include: Manufacture of food products; Manufacture of textiles; Manufacture of wood and paperrelated products; Manufacture of chemicals and chemical products; Manufacture of basic metals; Manufacture of machinery and equipment; and Construction.
} 
that are essential to validate the robustness of the results. Thus, in selecting service SMEs and other types of firms we consider, besides the criteria stated above, their inclusion in the samples for at least four consecutive years.

Based on the above criteria, we obtain four research samples with the following composition: i) sample of 610 service SMEs, of which 468 are in the market for the whole period of analysis, 66 enter the market during the period of analysis, and 76 leave the market during the period of analysis; ii) sample of 126 large service firms, of which 112 are in the market for the whole period of analysis, 4 enter the market during the period of analysis, and 10 leave the market during the period of analysis; iii) sample of 679 SMEs in manufacturing and construction industry sector, of which 506 are in the market for the whole period of analysis, 61 enter the market during the period of analysis, and 112 leave the market during the period of analysis; and iv) sample of 132 large manufacturing and construction firms, of which 107 are in the market for the whole period of analysis, 6 leave the market during the period of analysis, and 19 enter the market during the period of analysis.

The structure of the samples used in the paper is presented in Table 1.

(Insert Table 1 About Here)

\subsection{Descriptive Statistics}

Table 2 presents the descriptive statistics of the variables used in this study concerning service SMEs and other types of firm ${ }^{6}$.

(Insert Table 2 About Here)

\footnotetext{
${ }^{6}$ For service SMEs, the median of cash flow is 0.067818 , being 0.07231 for large service firms, 0.05018 for other SMEs, and 0.06661 for other large firms. The median of growth opportunities is 0.08516 for service SMEs, being 0.04561 for large service firms, 0.07918 for other SMEs, and 0.04019 for other large firms.

The median values of the cash flow and growth opportunities variables used for calculating the HGOLCF and LGOHCF variables are calculated according to what is presented in section 3. Methodology and Research Hypotheses.
} 
It stands out that service SMEs, compared to what occurs in other types of firm, have on average: $i$ ) greater growth opportunities and greater risk; and ii) less variation of debt, less debt, lower age, lower level of tangible assets and lower non-debt tax shields.

\section{Results}

\subsection{Pecking Order Theory}

Relationship between Financial Deficit and Debt-POT Model I

Table 3 presents the results of the survival analysis referring to Model I of Pecking Order Theory.

\section{(Insert Table 3 About Here)}

We find that financial deficit contributes to diminished probability of survival in service SMEs, which does not occur with respect to other types of firm. This result reveals the particular importance that financing restrictions may have for service SMEs, particularly for their survival.

The following tables present the results of the tests of Pecking Order Theory, regarding Model I.

(Insert Table 4 About Here)

(Insert Table 5 About Here) 
A positive relationship is found between financial deficit and debt variations in service SMEs and in the other types of firm considered. However, we find that the coefficient estimated that measures the relationship between financial deficit and debt variations is considerably higher in service SMEs than in other types of firm. The results of the Chow test confirm this, rejecting in all circumstances the null hypothesis of equality of the estimated parameters measuring relationships between financial deficit and debt variations in service SMEs and other types of firms.

Additionally, we find that the regression constant is not significant when the subject of analysis is service SMEs, but it is significant in the case of other types of firm. This result reinforces the idea of the particular importance of financial deficit in explaining variations of the debt of service SMEs, compared to the situation of other types of firm. In all regressions, the statistically significant relationship between the inverse Mill's ratio and variations in debt allows us to conclude that the inclusion of the inverse Mill's ratio in regressions was effective in controlling for possible bias in the results estimated.

\section{Determinants of Debt - POT Model II}

Table 6 presents the results of the survival analysis regarding Model II of Pecking Order Theory.

(Insert Table 6 About Here)

The results suggest that cash flow is important for the survival of service SMEs and other types of firm. However, the magnitude of the estimated parameters indicates that the importance of cash flows greater for service SMEs than for other types of firm. In addition, age seems to be important for the survival of service SMEs, and large service firms as well as for the survival of manufacturing and construction SMEs. Considering 
the magnitude of the estimated parameters, the importance of age seems to be greater for the survival of service SMEs.

The following tables present the results of the tests of Pecking Order Theory, concerning Model II.

(Insert Table 7 About Here)

(Insert Table 8 About Here)

In all of the regressions estimated, the results of the LM test indicate the rejection of the null hypothesis of irrelevance of non-observable individual effects. Therefore, an OLS regression is not the most appropriate way to estimate the relationships between determinants and debt in service SMEs and other types of firm. Additionally, the results of the Hausman test indicate the rejection of the null hypothesis of absence of correlation between non-observable individual effects and explanatory variables, and so nor is a regression considering random non-observable individual effects a suitable way to estimate the relationships between determinants and debt in service SMEs and other types of firm. This being so, the most correct way to estimate the relationships between determinants and debt in service SMEs and other types of firm is to consider fixed nonobservable individual effects in the regressions.

For service SMEs, we find that: $i$ ) greater cash flow, greater age and situations of low growth opportunities and high cash flow contribute to reduced debt; and ii) situations of high growth opportunities and low cash flow contribute to increased debt. For the remaining types of firm, cash flow is also found to contribute to reduced debt, the same is verified with respect to age for large service firms as well as for manufacturing and construction $\mathrm{SMEs}^{7}$. We also find that situations of high growth opportunities and low

\footnotetext{
${ }^{7}$ Although in this case the relationship is only statistically significant at $10 \%$ level.
} 
cash flow contribute to increased debt in large service firms as well as in manufacturing and construction SMEs, whereas situations of low growth opportunities and high cash flow contribute to reduced debt in manufacturing and construction SMEs. The results of the Chow test indicate that for all determinants, the null hypothesis of equality of estimated parameters is rejected. The result of the Chow test of parameters as a whole confirms those differences. In all regressions estimated, a statistically significant relationship is found between the inverse Mill's ratio and debt. We can therefore conclude that the inclusion of the inverse Mill's ratio in regressions was shown to be effective in solving possible bias in the results obtained.

\subsection{Trade-Off Theory}

Table 9 presents the results of the survival analysis regarding the Trade-Off Theory model.

(Insert Table 9 About Here)

From the results presented in Table 9 and considering the magnitude of the estimated parameters, we highlight the following: $i$ ) profitability is particularly important for the survival of service SMEs, risk being particularly important for diminished survival of this type of firm; and $i$ ) size and tangible assets are particularly important for the survival of SMEs, and large firms belonging to the manufacturing and construction industries.

Tables 10 and 11 present the results of the tests of Trade-Off Theory.

(Insert Table 10 About Here)

(Insert Table 11 About Here) 
Regardless of taking service SMEs or other types of firm as the subject of analysis, the results of the Hausman test indicate that we cannot reject the null hypothesis of validity of the instruments used. In addition, the results of the second-order autocorrelation tests indicate that we cannot reject the null hypothesis of absence of autocorrelation. Based on the results of the Hansen and second-order autocorrelation tests, we can consider the results obtained with the GMM system (1998) estimator as valid, and consequently open to interpretation.

We find that service SMEs: $i$ ) adjust actual debt toward target debt ratio; $i i$ ) reduce the level of debt as a function of greater profitability; and iii) reduce the level of debt as a function of greater size and higher levels of tangible assets. As for other types of firm, we find that: $i$ ) they adjust actual debt toward target debt ratio, $i i)$ reduce the level of debt as a function of greater profitability as well as of greater non-debt tax shields, while they increase the level of debt as a function of higher level of tangible assets debt; iii) manufacturing and construction SMEs increase the level of debt as a function of greater size $i v$ ) manufacturing and construction SMEs and large firms reduce the level of debt as a function of greater growth opportunities; $v$ ) large service firms as well as manufacturing and construction large firms increase the level of debt as a function of higher effective tax rates; and vi) manufacturing and construction SMEs and large firms diminish the level of debt as a function of greater risk.

Regarding the regressions presented in Table 10, but using the LSDVC (2005) estimator, the results presented in appendix are relatively similar to those presented in Table 10, with respect to sign, magnitude and statistical significance of the estimated parameters, which confirms the robustness of the results presented. The results of the Chow test indicate that we can reject the null hypothesis of equality of estimated parameters, except for the determinants of growth opportunities and risk in comparing 
service SMEs and large service firms, and those of growth opportunities and effective tax rate in comparing service SMEs, and manufacturing and construction SMEs. The result of the Chow test of estimated parameters as a whole confirms that there are significant differences in the determinants of debt in service SMEs and other types of firm.

Inclusion of the inverse Mill's ratio in the regressions was also found to be effective in controlling for possible bias in the estimated results, since a statistically significant relationship is found between the inverse Mill's ratio and debt.

\section{Discussion of Results}

The impact of financial deficit on debt variations in service SMEs $(B=0.90911)$ is greater than in the context of large service firms $(B=0.50172)$, manufacturing and construction SMEs $(B=0.48091)$ as well as for manufacturing and construction large firms $(B=0.39440)$. The results of the Chow test confirm these differences. In addition, the regression constant regarding the relationship between financial deficit and debt variations in service SMEs is not statistically significant, but it is not the case in any other type of firm. This empirical evidence indicates that recourse to debt by service SMEs is considerably more influenced by insufficient internal finance than what occurs in other types of firm.

The relationships identified between determinants and debt in service SMEs and other types of firm allow us to draw various conclusions. Firstly, we find that service SMEs reduce recourse to debt in situations of low growth opportunities and high cash flow, which agrees with the forecasts of Pecking Order Theory. This result is not found for any other type of firm. Secondly, greater cash flow implies less recourse to debt in service SMEs and other types of firm, corroborating what is forecast by Pecking Order 
Theory. However, the magnitude of that reduction in recourse to debt is greater in service SMEs than in other types of firm. The results of the Chow test confirm those differences. Thirdly, greater age contributes to reduced recourse to debt in service SMEs and large firms, and in manufacturing and construction SMEs, corroborating Pecking Order Theory. The magnitude of reduction in debt, as a consequence of greater age, is greater in service SMEs than in other types of firm. This result is also confirmed by the Chow test. Therefore, age is not a determinant of debt for large manufacturing and construction firms. Fourthly, situations of high growth opportunities and low cash flow contribute to increased recourse to debt in service SMEs and large firms, and in manufacturing and construction SMEs, corroborating what is forecast by Pecking Order Theory. However, the magnitude of the increase in debt is greater in service SMEs than in large service firms and manufacturing and construction SMEs, a situation that is confirmed by the results of the Chow test. As for large manufacturing and construction firms, we find that situations of high growth opportunities and low cash flow imply neither more nor less recourse to debt.

The multiple empirical evidence obtained allows us to conclude that service SMEs turn more to debt as a function of financial deficit and high growth opportunities and low cash flow, and turn less to debt as a function of cash flow, age and situations of low growth opportunities and high cash flow than is the case in other types of firm. We can therefore conclude that capital structure decisions in service SMEs are closer to the forecasts of Pecking Order Theory than the capital structure decisions of other types of firm, and so we can accept the previously formulated hypothesis $\mathrm{H} 1$ as valid.

The importance of internal finance in SME activity (Pettit and Singer, 1985; Ang 1992; Scherr and Hulburt 2001; López-Gracia and Sánchez-Andújar, 2008; Ramalho and Silva 2009) seems to be particularly strong in service SMEs. This importance is 
reinforced by the particular relevance of cash flow for the survival of service SMEs, and also by the fact that financial deficit contributes to diminishing the survival of service SMEs that does not occur in other types of firm. The conclusions of Franco and Haase (2010) that financing restrictions may affect SME survival seem to be particularly relevant in service SMEs.

The smaller size of SMEs, and consequently greater probability of bankruptcy (Pettit and Singer, 1985; Ang, 1991), associated with higher level of intangible assets (Cruz-Ros et al., 2010), may decisively contribute to service SMEs to have particular difficulty in obtaining debt. Therefore, service SMEs may turn to debt only in cases of need, i.e., when internal funds are clearly insufficient to finance their activities.

The empirical evidence obtained corroborates the conclusions of Cressy and Olofsson (1997) and Abor (2007), since service SMEs' lower level of tangible assets compared to manufacturing and construction ${ }^{8}$, SMEs' level of tangible assets may decisively contribute to increasing the problems of information asymmetry faced by service SMEs in the relationships with creditors, contributing to internal finance being their main source of funding.

Regarding the applicability of the assumptions of Trade-Off Theory to the capital structure decisions of service SMEs and those of other types of firm, we find that their level of adjustment of actual debt level toward target debt ratio is lower $(\alpha=0.21880)$ than the level of adjustment verified in large service firms $(\alpha=0.40808)$, in manufacturing and construction SMEs $(\alpha=0.37069)$ as well as in manufacturing and construction large firms $(\alpha=0.52284)$. The results of the Chow test confirm the differences in the adjustments of actual debt level toward the target debt ratio between service SMEs and other types of firm.

\footnotetext{
${ }^{8}$ From the results presented in Table 2, we see that on average, the tangible assets of service SMEs are 0.29778 , while the tangible assets of manufacturing and construction SMEs are 0.34997.
} 
With respect to the relationships between determinants and debt, the empirical evidence allows us to draw important conclusions regarding the applicability of the assumptions of Trade-Off Theory to the capital structure decisions of service SMEs and other types of firm. Firstly, greater profitability does not contribute to increased recourse to debt in service SMEs and other types of firm, which does not corroborate what is forecast by Trade-Off Theory, because firms do not take advantage of greater profitability to increase debt tax-shields, arising from greater level of debt. Secondly, greater growth opportunities, greater non-debt tax shields, and greater risk imply less recourse to debt by SMEs and large manufacturing and construction firms, results which are in accordance with Trade-Off Theory. In service SMEs, growth opportunities, nondebt tax shields, and risk are not determinants of their level of debt. In large service firms, only non-debt tax shields are a determinant of debt, but growth opportunities and risk are not determinants of debt. Thirdly, higher effective tax rates contribute to greater recourse to debt by large service firms and large manufacturing and construction firms, these results corroborating the forecasts of Trade-Off Theory. Higher effective tax rates are not a determinant of debt in service SMEs and large service firms.

Fourthly, greater size contributes to increased recourse to debt by service and manufacturing/construction SMEs, corroborating the forecasts of Trade-Off Theory, but it is not a determinant of debt in large service firms and large manufacturing/construction firms. In addition, greater tangibility of assets contributes to service SMEs, and large service as well as manufacturing/construction firms turning more to debt, these results agreeing with Trade-Off Theory. It stands out that size and asset tangibility are of greater relative importance for increased recourse to debt in service SMEs than in other types of firm, a situation confirmed by the results of the Chow test. 
Contrary to our expectations, greater size and higher level of tangible assets are of greater relative importance for service SMEs turning to debt, compared to the case in other types of firm. Considering only relationships between size and debt, and between tangible assets and debt, we would conclude that the capital structure decisions of service SMEs are closer to the forecasts of Trade-Off Theory than the capital structure decisions of other types of firm. These results may arise from the importance of greater size and level of tangible assets to reduce the problems of information asymmetry, therefore creditors grant debt in more favourable terms to service SMEs. The marginal importance of size and tangible assets to obtain debt may be greater for service SMEs than for other types of firm.

Service SMEs have a lower level adjustment of actual debt toward target debt ratio than is found in other types of firms. Additionally, greater growth opportunities, greater non-debt tax shields and greater risk do not imply less recourse to debt in service SMEs. Higher effective tax rates do not imply more recourse to debt in service SMEs, unlike what occurs in the majority of the situations in other types of firm.

Although not for all determinants, the empirical evidence suggests that the capital structure decisions of service SMEs are further from the assumptions of Trade-Off Theory than the capital structure decisions of other types of firm, and so we can accept the previously formulated hypothesis $\mathrm{H} 2$ as partially valid.

It stands out that service SMEs have lower speed of adjustment of the actual debt level toward target debt ratio than other types of firm. This result suggests the lower importance that the goal to reaching the target debt ratio has for service SMEs compared to the case in other types of firm. Contributing to these results are the smaller size and the lower levels of tangible assets of service SMEs that imply high transaction costs, 
which may explain the lower speed of adjustment of actual level of debt toward the target debt ratio.

Värlander and Julien (2010) conclude that personal relationships established with clients can be particularly important to increase performance in service firms. This important conclusion by the authors can be extended to the relationships between the owners/managers of service SMEs and creditors. Indeed, establishing trusting and longlasting relationships may be particularly important for reducing the information asymmetry between service SME owners/managers and creditors, contributing to lower transaction costs in obtaining debt. Therefore, service SMEs may increase the speed of adjustment of the actual level of debt toward target debt ratio.

On the one hand, the fact that service SMEs do not reduce the level of debt as a function of greater growth opportunities, level of risk and non-debt tax shields, and do not increase the level of debt as a function of tax rate, shows that these firms are less concerned with a trade-off between the benefits and costs of debt compared to other types of firm. On the other hand, the fact that size and tangible assets are particularly relevant for service SMEs to obtain debt indicates that greater size and high level of tangible assets may be determinant for service SMEs to consider more effectively a trade-off between the benefits and costs of debt.

The multiple empirical evidence obtained in this study clearly indicates that problems of information asymmetry between firm owners/managers and creditors can be particularly relevant in the case of service SMEs. Indeed, in these circumstances, as Elston and Audretsch (2009) conclude that firms with high information asymmetry associated with their activities may only resort to debt when internal finance is clearly insufficient. 
Reed and Storrud-Barnes (2009) conclude that economies of scale and the power of the market may be particularly relevant for service firms being able to increase their performance. There may be an important connection between the conclusions of Reed and Storrud-Barnes (2009) and the empirical evidence obtained in this paper. Greater size and higher level of tangible assets may contribute to greater recourse to debt in service SMEs on particularly advantageous terms. When internal finance is insufficient, obtaining debt in advantageous terms may be fundamental for service SMEs being able to take advantage of the multiple investment opportunities arising, which allows to attain a economies of scale and market power, consequently increasing their performance.

Hall et al. (2000) for British SMEs and Bhaird and Lucey (2009) for Irish SMEs conclude that differences between capital structure decisions in service and manufacturing SMEs are not significant. Identical conclusions are obtained by Cressy and Olofsson (1997) for Swedish SMEs, and by Abor (2007) for Ghanaian SMEs. Unlike the conclusions of other empirical studies, we find that the capital structure decisions of service SMEs differ considerably from those of other types of firm, such as SMEs and large firms in the manufacturing and construction industry. We also find that the capital structure decisions of service SMEs are different from those of large service firms.

It is also important to mention that the capital structure decisions of service SMEs are closer to the assumptions of Pecking Order Theory, whereas the structure decisions of large manufacturing and construction firms are closer to the assumptions of TradeOff Theory. This difference in the financing behaviour between service SMEs and large manufacturing and construction firms may be due to the effects of size (i.e., small versus large firms) and tangible assets (service firms versus manufacturing and 
construction industries), reinforcing the importance of these two determinants in explaining differences between the capital structure decisions of service SMEs and those of other types of firm.

\section{Conclusion and Implications}

Using four research samples: i) 610 SMEs, ii) 126 large service firms; iii) 679 manufacturing and construction SMEs; and iv) 132 large manufacturing and construction firms, and resorting to the two-step estimation process, this paper analyses if the capital structure decisions of service SMEs are different from those of other types of firm.

The multiple empirical evidence obtained allow us to conclude that the capital structure decisions of service SMEs are different from those of other types of firm. Firstly, variations of debt in service SMEs are found to be considerably more influenced by situations of financial deficit than the debt variations in other types of firm. In addition, compared to other types of firms, we find that greater relative importance of cash flow, age and situations of low growth opportunities and high cash flow for reduced recourse to debt in service SMEs. Additionally, the situations of high growth opportunities and low cash flow have greater importance for increased recourse to debt in service SMEs. These results clearly indicate that the capital structure decisions of service SMEs are closer to the forecasts of Pecking Order Theory than are the capital structure decisions of other types of firm.

Secondly, the speed of adjustment of actual level of debt toward target debt ratio is lower in service SMEs than in other types of firm. This result shows that service SMEs face higher transaction costs in obtaining debt than other types of firm. Furthermore, service SMEs do not decrease the level of debt as a function of greater growth 
opportunities, greater non-debt tax shields and greater risk. However, service SMEs do do not increase the level of debt as a function of higher effective tax rates, unlike what occurs in large service, manufacturing and construction firms as well as in manufacturing and construction SMEs for some of the determinants named above.

Thirdly, size and asset tangibility are of greater relative importance for greater level of debt for service SMEs compared to the case of other types of firm. This result allows us to conclude that size and tangible assets are particularly important for lessening problems of information asymmetry in the relationships between the owners/managers of service SMEs and creditors. Additionally, given that greater size and higher level of tangible assets contribute to reduced information asymmetry in relationships between service SME owners/managers and creditors, service SMEs can begin to consider more effectively in their strategies to reach the target debt ratio, which implies that firms balance the benefits and costs of debt.

The multiple empirical evidence obtained in this study allow us to make various contributions to the literature on SME capital structure in general, and to capital structure in service SMEs in particular. The results show that the capital structure decisions of service SMEs are considerably different from those of other types of firm. The empirical evidence obtained here shows that service SMEs resort to debt more as a consequence of insufficient internal finance, and less with the aim of attaining a target debt ratio that balances the benefits and costs of debt. The capital structure decisions of service SMEs are closer to the suppositions of Pecking Order Theory, and further removed from those of Trade-Off Theory, than the capital structure decisions of other types of firm.

The paper also makes a relevant theoretical contribution to the literature on SME capital structure in general, and service SMEs in particular: size and tangible assets can 
be particularly relevant for firms that face problems of information asymmetry, as may be the case with service SMEs. Consequently, greater size and higher level of tangible assets allow service SMEs being able to consider more effectively in their capital structure decisions a trade-off between the benefits and cost of debt, and not resorting almost exclusively to debt to cover insufficiencies of internal finance. In other words, size and tangible assets are important determinants for service SMEs, particularly affected by problems of information asymmetry, do not consider only the assumptions of Pecking Order Theory, being able to consider also those of Trade-Off Theory in their capital structure decisions.

The empirical evidence obtained in this paper allows us to make suggestions for policy-makers and the owners/managers of service SMEs. Given the importance of service SMEs in Europe in general, and in Portugal in particular, to policy-makers we suggest the creation of lines of credit especially directed for SMEs that are financial and economically sustainable, but facing obstacles in obtaining debt. The creation of lines of credit would allow service SMEs to take advantage of the multiple investment opportunities that in turn would contribute to promote firms' economies of scale, and consequently to increased employment and economic growth.

To the owners/managers of service SMEs we suggest to establish trusting, longlasting relationships with creditors, so as to lessen problems of information asymmetry, which contributes to obtain debt on more advantageous terms.

Given that firm's growth may influence funding needs, this study has the limitation regarding the absence of the analysis of the applicability of the Pecking Order Theory and Trade-off Theory as a function of the growth levels of the service SMEs and other types of firm. For future researches, we suggest to study the applicability of representative models of Pecking Order Theory and Trade-Off Theory to the capital 
structure decisions of service SMEs and other types of firm considering the firms' levels of growth. 


\section{APPENDIX A: Trade - Off Theory Model - LSDVC (2005) Estimator}

Table A1: Trade- Off Theory Model - LSDVC (2005) Estimator

\begin{tabular}{|c|c|c|c|c|}
\hline \multirow{3}{*}{ Independent variable } & \multicolumn{4}{|c|}{ Dependent Variable: $\mathrm{D}_{\mathrm{i}, \mathrm{t}}$} \\
\hline & \multirow[t]{2}{*}{ Service SMEs } & \multirow{2}{*}{ Large Service Firms } & \multirow{2}{*}{ Other SMEs } & \multirow{2}{*}{ Other Large Firms } \\
\hline & & & & \\
\hline \multirow[t]{2}{*}{$\mathrm{D}_{\mathrm{i}, \mathrm{t}-1}$} & $0.83421 * * *$ & $0.56172 * * *$ & $0.65162 * * *$ & $0.51108 * * *$ \\
\hline & $(0.07882)$ & $(0.06019)$ & $(0.05516)$ & $(0.05314)$ \\
\hline \multirow{2}{*}{$\mathrm{PROF}_{i, t}$} & $-0.85152 * * *$ & $-0.51018 * * *$ & $-0.65160 * * *$ & $-0.37091 * * *$ \\
\hline & $(0.11334)$ & $(0.06541)$ & $(0.09445)$ & (0.04919) \\
\hline \multirow[t]{2}{*}{$\mathrm{SIZE}_{\mathrm{i}, \mathrm{t}}$} & $0.07617 * * *$ & $0.03483 *$ & $0.05718 * * *$ & 0.00988 \\
\hline & $(0.02626)$ & $(0.01770)$ & $(0.01309)$ & $(0.01445)$ \\
\hline \multirow{2}{*}{$\mathrm{TANG}_{\mathrm{i}, \mathrm{t}}$} & $0.45612 * * *$ & $0.18919 * *$ & $0.21909 * * *$ & $0.13919 *$ \\
\hline & $(0.12681)$ & $(0.09762)$ & $(0.07679)$ & $(0.07018)$ \\
\hline \multirow{2}{*}{$\mathrm{GO}_{\mathrm{i}, \mathrm{t}}$} & -0.01408 & 0.02056 & $-0.03981 * *$ & $-0.07909 * * *$ \\
\hline & $(0.05181)$ & $(0.07142)$ & $(0.01912)$ & $(0.02398)$ \\
\hline \multirow[t]{2}{*}{ NDTS $_{i, t}$} & 0.02718 & $-0.21012 * * *$ & $-0.29667 * * *$ & $-0.32019 * * *$ \\
\hline & $(0.12871)$ & $(0.05671)$ & (0.09559) & $(0.09382)$ \\
\hline \multirow[t]{2}{*}{$\mathrm{ETR}_{\mathrm{i}, \mathrm{t}}$} & 0.00453 & $0.067812 * * *$ & -0.01299 & $0.08108 * * *$ \\
\hline & $(0.021061)$ & $(0.02171)$ & $(0.03617)$ & $(0.02284)$ \\
\hline \multirow[t]{2}{*}{$\mathrm{EVOL}_{\mathrm{i}, \mathrm{t}}$} & 0.01415 & 0.008905 & $-0.02109 * * *$ & $-0.02223 * * *$ \\
\hline & $(0.02718)$ & $(0.00987)$ & $(0.00901)$ & $(0.00443)$ \\
\hline \multirow[t]{2}{*}{$\lambda_{\mathrm{i}, \mathrm{t}}$} & $-18.7762 * * *$ & $-12.6563 * * *$ & $-17.6512 * * *$ & $-14.0201 * * *$ \\
\hline & (4.2171) & (3.4092) & (3.5901) & $(4.1451)$ \\
\hline Firms & 534 & 116 & 567 & 113 \\
\hline Observations & 3097 & 685 & 3258 & 656 \\
\hline
\end{tabular}

Notes: 1. Standard deviations in parenthesis. 2. *** statistical significance at the $1 \%$ level; ** statistical significance at the 5\% level; * statistical significance at the $10 \%$ level. 3 . The estimates include time dummy variables, but not shown. 


\section{References}

Abor J (2007) "Industry Classification and the Capital Structure of Ghanaian SMEs". Stud Econ Financ 23: 207 - 219

Ang J (1976) “The Intertemporal Behaviour of Corporate Debt Policy”. J Financ Quant Anal 11: 555-566

Ang J (1991) "Small Business Uniqueness \& The Theory of Financial Management”. J Small Bus Financ 1: 1-13

Ang J (1992) "On the Theory of Finance For Privately Held Firms". J Small Bus Finance 1: 185-203

Arellano M, Bond S (1991) “Some Tests of Specification For Panel Data: Monte Carlo Evidence and an Application to Employment Equations”. Rev Econ Stud 58: 277297

Barclay M, Smith C, Morellec E (2006) "On the Debt Capacity of Growth Opportunities". J Bus 79: 37-59

Bhaird C, Lucey B (2010) "Determinants of Capital Structure in Irish SMEs". Small Bus Econ 35: $357-375$

Blundell M, Bond S (1998) "Initial Conditions and Moment Restrictions in Dynamic Panel Data Models”. J Econometrics 87: 115-143

Bradley M, Jarrell G, Kim E (1984) "On the Existence of an Optimal Capital Structure: Theory and Evidence”. J Financ 39: 857-878

Bruno G (2005) “Approximating the Bias of LSDV Estimator for Dynamic Unbalanced Panel Data Models”. Econ Lett 87: 361-366

Cressy R, Olofsson C (1997) "European SME financing: an Overview". Small Bus Econ 9: 87-96 
Cruz-Ros S, Cruz T, Pérez-Cabañero C (2010) "Marketing Capabilities, Stakeholdrs` Satisfaction, and Performance”. Serv Bus 4: 209-223

DeAngelo H, Masulis R (1980) "Optimal Capital Structure Under Corporate and Personal Taxation". J Financ Econ 8: 3-29

Diamond D (1989) "Reputation Acquisition in Debt Markets". J Polit Econ 97: 828-862

Elston J, Audretsch D (2011) "Financing the Entrepreneurial Decision: An Empirical Approach Using Experimental Data on Risk Attitudes”, Small Bus Econ 36: 209-222

Fleck D (2010) "Why we Should Dare to Manage Growth Responsibly". Manag Decis 48: $1529-1538$.

Franco M, Haase H (2010) "Failure Factors in Small and Medium-Sized Enterprises: Qualitative Study From an Attributional Perspective”. Int Ent Manag J 6: 503-521

Hall G, Hutchinson P, Michaelas N (2000) "Industry Effects on the Determinants of Unquoted SMEs`Capital Structure”. Int J Econ Bus 7: 297 - 312

Harris M, Raviv A (1991) “The Theory of Capital Structure”. The J of Fin 46: 297-355

Haugen R, Senbet L (1986) “Corporate Finance and Taxes: A Review”. Financ Manage Autumn: 5-21

Heckman J (1979) "Sample Selection Bias as a Specification Error". Econometrica 47: $153-161$

Holmes S, Kent P (1991) “An Empirical Analysis of the Financial Structure of Small and Large Australian Manufacturing Enterprises”. J Small Bus Financ 2: 141-154

Hyytinen A, Pajarinen M (2005) "Financing of Technology - Intensive Small Businesses: Some Evidence on the Uniqueness of the ICT Sector”. Inform Econ Policy 17: 115-132

Jalilvand, A., Harris R (1984) "Corporate Behaviour in Adjusting to Capital Structure and Dividend Targets: An Econometric Study". J Financ 39: 127-145 
Jensen M, Meckling W (1976) "Theory of the Firm: Managerial Behavior, Agency Costs and Ownership Structure”. J Financ Econ 3: 305-360

Kim E (1978) “A Mean-Variance Theory of Optimal Capital Structure and Corporate Debt Capacity". J Financ 33: 45-63

Kraus A, Litzenberger R (1973) “A State-Preference Model of Optimal Financial Leverage”. J Financ 28: 911-922

Lev B, Pekelman D (1975) “A Multiperiod Adjustment Model For the Firm's Capital Structure”. J Financ 30: 75-92

López - Gracia J, Sánchez - Andújar S (2007) "Financial Structure of the Family Business: Evidence From a Group of Small Spanish Firms”. Fam Bus Rev 20: 269287

López - Gracia J, Sogorb - Mira F (2008) "Testing Trade - Off and Pecking Order Theories in Spanish SMEs". Small Bus Econ 31: 117-136

MacKie-Mason J (1990) “Do Taxes Affect Corporate Financing Decisions?”. J Financ 45: $1471-1493$

McConnell J, Servaes H (1995) "Equity Ownership and the Two Faces of Debt". J Financ Econ 39: 131-157

Modigliani F, Miller M (1958) "The Cost of Capital, Corporation Finance and Theory of Investment”. Am Econ Rev 48: 261-297

Modigliani F, Miller M (1963) "Corporate Income Taxes and the Cost of Capital: a Correction”. Am Econ Rev 53: 433-443

Myers S (1977) “The Determinants of Corporate Borrowing”. J of Fin Econ 5: 147-176

Myers S (1984) “The Capital Structure Puzzle”. J Financ 57: 575-592

Myers S., Majluf N (1984) “Corporate Financing and Investment Decision When Firms Have Information That Investors do Not Have”. J Financ Econ 13: 187-221 
National Institute of Statistics (2010) Structural Business Statistics Studies, Lisbon, Portugal

Pettit R, Singer R (1985) "Small Business Finance: A Research Agenda". Financ Manage Autumn: 47-60

Rajan R, Zingales L (1995) "What do We Know About Capital Structure? Some Evidence From International Data”. J Financ 50: 1421-1460

Ramalho J, Silva J (2009) “A Two - Part Fractional Regression Model For the Financial Leverage Decisions of Micro, Small, Medium and Large Firms". Quant Financ 9: $621-636$

Reed R, Storrud-Barnes S (2009) "Systematic Performance Differences Across the Manufacturing - Service Continuum". Serv Bus 3: 319-339

Revest V, Sapio A (2010) "Financing Technology-Based Small Firms in Europe: What do we Know?". Small Bus Econ Forthcoming: 1-27

Scherr F, Hulburt H (2001) “The Debt Maturity Structure of Small Firms". Financ Manage spring: 85-111

Scott J (1977) “Bankruptcy, Secured Debt, and Optimal Capital Structure”. J Financ 32: $1-19$

Shyam-Sunder L, Myers S (1999) “Testing Static Trade-Off Against Pecking Order Models of Capital Structure”. J Financ Econ 51: 219-244

Stulz R (1990) “Managerial Discretion and Optimal Financing Policies”. J Financ Econ 26: $3-27$

Taggart R (1977) “A Model of Corporate Financing Decisions”. J Financ, 32: 14671484

Värlander S, Julien A (2010) "The Effect of the Internet on From-Line Employee Skills: Exploring Banking in Sweden and France”. Serv Ind J 30: 1245-1261 
Table 1: Sample Description

\begin{tabular}{|c|c|c|c|c|}
\hline & Service SMEs & Large Service Firms & Other SMEs & Other Large Firms \\
\hline Incumbent firms in all period $1999-2006$ & 468 & 112 & 506 & 107 \\
\hline Firms entering in the period $1999-2006$ & 66 & 4 & 61 & 6 \\
\hline Firms exiting in the period $1999-2006$ & 76 & 10 & 112 & 19 \\
\hline Total Firms & 610 & 126 & 679 & 132 \\
\hline
\end{tabular}

Table 2: Descriptive Statistics

\begin{tabular}{|c|c|c|c|c|c|c|c|c|c|c|c|c|}
\hline & \multicolumn{4}{|c|}{ Service SMEs } & \multicolumn{3}{|c|}{ Large Service Firms } & \multicolumn{2}{|c|}{ Other SMEs } & \multicolumn{3}{|c|}{ Other Large Firms } \\
\hline Variable & $\mathrm{N}$ & Mean & S.D. & $\mathrm{N}$ & Mean & S. D. & $\mathrm{N}$ & Mean & S.D & $\mathrm{N}$ & Mean & S.D: \\
\hline$\Delta \mathrm{LEV}_{\mathrm{i}, \mathrm{t}}$ & 3933 & 174341 & 965121 & 851 & 189182 & 987161 & 4348 & 187901 & 1011299 & 872 & 180067 & 997651 \\
\hline $\mathrm{FD}_{\mathrm{i}, \mathrm{t}}$ & 3933 & -240912 & 961521 & 851 & -161820 & 988774 & 4348 & -389184 & 1490198 & 872 & -140921 & 871821 \\
\hline $\mathrm{D}_{\mathrm{i}, \mathrm{t}}$ & 3933 & 0.64503 & 0.17661 & 851 & 0.67490 & 0.19714 & 4348 & 0.66149 & 0.18893 & 872 & 0.70112 & 0.20117 \\
\hline $\mathrm{CF}_{\mathrm{i}, \mathrm{t}}$ & 3933 & 0.06819 & 0.10116 & 851 & 0.07413 & 0.11998 & 4348 & 0.04895 & 0.08113 & 872 & 0.06891 & 0.09668 \\
\hline $\mathrm{AGE}_{\mathrm{i}, \mathrm{t}}$ & 3933 & 2.70330 & 0.70182 & 851 & 2.81828 & 0.75162 & 4348 & 2.79812 & 0.73421 & 872 & 2.83717 & 0.77710 \\
\hline $\mathrm{HGOLCF}_{\mathrm{i}, \mathrm{t}}$ & 3933 & 0.07616 & 0.27881 & 851 & 0.058919 & 0.20981 & 4348 & 0.06172 & 0.24516 & 872 & 0.05561 & 0.19781 \\
\hline $\mathrm{LGOHCF}_{\mathrm{i}, \mathrm{t}}$ & 3933 & -0.04891 & 0.18912 & 851 & -0.05616 & 0.20182 & 4348 & -0.03511 & 0.16172 & 872 & -0.02871 & 0.14152 \\
\hline $\mathrm{PROF}_{\mathrm{i}, \mathrm{t}}$ & 3933 & 0.05211 & 0.08089 & 851 & 0.05122 & 0.07944 & 4348 & 0.05291 & 0.08251 & 872 & 0.05091 & 0.07871 \\
\hline SIZE $_{i, t}$ & 3933 & 16.5361 & 2.41321 & 851 & 17.9485 & 2.88990 & 4348 & 16.5781 & 2.38981 & 872 & 18.0123 & 2.93172 \\
\hline $\mathrm{TANG}_{\mathrm{i}, \mathrm{t}}$ & 3933 & 0.29778 & 0.21899 & 851 & 0.30918 & 0.22121 & 4348 & 0.34997 & 0.23996 & 872 & 0.37719 & 0.25712 \\
\hline $\mathrm{GO}_{\mathrm{i}, \mathrm{t}}$ & 3933 & 0.08981 & 0.32777 & 851 & 0.04717 & 0.25667 & 4348 & 0.07654 & 0.27013 & 872 & 0.04205 & 0.23916 \\
\hline NDTS $_{i, t}$ & 3933 & 0.03749 & 0.03311 & 851 & 0.04018 & 0.04281 & 4348 & 0.04654 & 0.03781 & 872 & 0.04559 & 0.04609 \\
\hline ETR $_{i, t}$ & 3933 & 0.41821 & 1.58929 & 851 & 0.44681 & 1.60812 & 4348 & 0.41414 & 1.56712 & 872 & 0.46717 & 1.63421 \\
\hline $\mathrm{EVOL}_{\mathrm{i}, \mathrm{t}}$ & 3933 & 1.64564 & 2.89843 & 851 & 1.56717 & 2.80198 & 4348 & 1.40911 & 2.5989 & 872 & 1.37812 & 2.57812 \\
\hline
\end{tabular}

Table 3: Survival Analysis - Impact of Financial Deficit on Debt Variations - Pecking Order Theory - Model I

\begin{tabular}{|c|c|c|c|c|}
\hline & \multicolumn{4}{|c|}{ Dependent Variable: $\operatorname{Pr}\left(\delta_{\mathrm{i}, \mathrm{t}}=1\right)$} \\
\hline & Service SMEs & Large Service Firms & Other SMEs & Other Large Firms \\
\hline \multicolumn{5}{|l|}{ Independent variables } \\
\hline \multirow{2}{*}{$\mathrm{FD}_{\mathrm{i}, \mathrm{t}}$} & $-0.000007 * * *$ & -0.0000001 & -0.000002 & 0.000001 \\
\hline & $(0.0000002)$ & $(0.0000002)$ & $(0.0000002)$ & $(0.000001)$ \\
\hline \multirow[t]{2}{*}{ CONS } & $0.00417 * * *$ & $0.05161 * * *$ & $0.06667 * * *$ & $0.05142 * * *$ \\
\hline & $(0.00103)$ & $(0.00415)$ & $(0.00871)$ & $(0.00910)$ \\
\hline Pseudo $\mathrm{R}^{2}$ & 0.16162 & 0.03421 & 0.03019 & 0.02771 \\
\hline Log Likelihood & -98.10 & -86.44 & -81.17 & -90.12 \\
\hline Firms & 610 & 126 & 679 & 132 \\
\hline Observations & 3933 & 851 & 4348 & 872 \\
\hline
\end{tabular}

Notes: 1. Standard deviations in parenthesis. 2. *** statistical significance at the $1 \%$ level; ** statistical significance at the 5\% level; * statistical significance at the $10 \%$ level. 3 . The estimates include time dummy variables, but not shown.

Table 4: Impact of Financial Deficit on Debt Variations - Pecking Order Theory - Model I

\begin{tabular}{ccccc}
\hline & & \multicolumn{2}{c}{ Dependent Variable: $\Delta$ LEV } & \\
& Service SMEs & Large Service Firms & Other SMEs & Other Large Firms \\
Independent variables & & & & \\
$\mathrm{FD}_{\mathrm{i}, \mathrm{t}}$ & $0.90911^{* * *}$ & $0.50172 * * *$ & $0.48091 * * *$ & $0.39440^{* * *}$ \\
& $(0.08002)$ & $(0.06571)$ & $(0.07172)$ & $(0.06151)$ \\
$\lambda_{\mathrm{i}, \mathrm{t}}$ & $-16.091 * * *$ & $-12.819 * * *$ & $-15.104 * * *$ & $-13.876^{* * *}$ \\
& $(2.09213)$ & $(1.56109)$ & $(1.8718)$ & $(1.76201)$ \\
$\mathrm{CONS}$ & 54891 & $159145^{* * *}$ & $163409 * * *$ & $187012^{* * *}$ \\
$\mathrm{~F}(\mathrm{~N}(0.1))$ & $(52910)$ & $(54091)$ & $(53907)$ & $(56118)$ \\
$\mathrm{R}^{2}$ & 157.12 & $123.01 * * *$ & $117.23 * * *$ & $108.90^{* * *}$ \\
Firms & 0.72839 & 0.56121 & 0.51447 & 0.46712 \\
Observations & 534 & 116 & 567 & 113 \\
\hline
\end{tabular}

Notes: 1. Standard deviations in parenthesis. 2. *** statistical significance at the $1 \%$ level; ** statistical significance at the 5\% level; * statistical significance at the $10 \%$ level. 3 . The estimates include time dummy variables, but not shown. 
Table 5: Chow Test - Impact of Financial Deficit on Debt Variations - Pecking Order Theory Model I

Notes: 1. Probabilities in parenthesis. 2. *** statistical significance at the $1 \%$ level; ** statistical significance at the $5 \%$ level; * statistical significance at the $10 \%$ level.

Table 6: Survival Analysis - Determinants of Debt - Pecking Order Theory - Model II



Notes: 1. Standard deviations in parenthesis. 2. *** statistical significance at the $1 \%$ level; ** statistical significance at the 5\% level; * statistical significance at the $10 \%$ level. 3 . The estimates include time dummy variables, but not shown.

Table 7: Determinants of Debt - Pecking Order Theory - Model II

\begin{tabular}{|c|c|c|c|c|}
\hline \multirow{3}{*}{ Independent variable } & \multicolumn{4}{|c|}{ Dependent Variable: $\mathrm{D}_{\mathrm{i}, \mathrm{t}}$} \\
\hline & Service SMEs & Large Service Firms & Other SMEs & Other Large Firms \\
\hline & & & & \\
\hline \multirow{2}{*}{$\mathrm{CF}_{\mathrm{i}, \mathrm{t}}$} & $-0.81734 * * *$ & $-0.46712 * * *$ & $-0.30182 * *$ & $-0.18781 * *$ \\
\hline & (0.15161) & $(0.12843)$ & $(0.14538)$ & $(0.09332)$ \\
\hline \multirow[t]{2}{*}{$\mathrm{AGE}_{\mathrm{i}, \mathrm{t}}$} & $-0.08812 * * *$ & $-0.04998 * *$ & $-0.02091 *$ & 0.01201 \\
\hline & $(0.01784)$ & $(0.02419)$ & $(0.01197)$ & $(0.02189)$ \\
\hline \multirow[t]{2}{*}{$\mathrm{HGOLCF}_{\mathrm{i}, \mathrm{t}}$} & $0.09812 * * *$ & $0.05120 * * *$ & $0.04891 * * *$ & 0.00891 \\
\hline & $(0.02810)$ & $(0.01671)$ & $(0.01458)$ & $(0.02515)$ \\
\hline \multirow[t]{2}{*}{$\mathrm{LGOHCF}_{\mathrm{i}, \mathrm{t}}$} & $-0.06718 * * *$ & -0.02066 & -0.02797 & 0.01562 \\
\hline & $(0.015462)$ & $(0.01982)$ & $(0.02568)$ & (0.03899) \\
\hline \multirow[t]{2}{*}{$\lambda_{\mathrm{i}, \mathrm{t}}$} & $-11.4938 * * *$ & $-12.6670 * * *$ & $-15.4312 * * *$ & $-14.8182 * * *$ \\
\hline & $(2.05169)$ & $(2.16715)$ & $(3.9173)$ & $(4.0182)$ \\
\hline \multirow[t]{2}{*}{ CONS } & 0.01154 & $0.02191 *$ & 0.01341 & $0.05162 * * *$ \\
\hline & $(0.01348)$ & $(0.01047)$ & $(0.01216)$ & $(0.01516)$ \\
\hline $\mathrm{R}^{2}$ & 0.51527 & 0.46781 & 0.41929 & 0.27172 \\
\hline $\mathrm{F}(\mathrm{N}(0.1))$ & $111.90 * * *$ & $103.34^{* * * *}$ & $102.08 * * *$ & $81.12 * * *$ \\
\hline LM Test & $156.90 * * *$ & $142.05 * * *$ & $150.09 * * *$ & $134.86 * * *$ \\
\hline Hausman Test & $57.56 * * *$ & $49.89 * * *$ & $60.10 * * *$ & $52.33 * * *$ \\
\hline Firms & 534 & 116 & 567 & 113 \\
\hline Observations & 3575 & 798 & 3779 & 764 \\
\hline
\end{tabular}

Notes: 1. Standard deviations in parenthesis. 2. *** statistical significance at the $1 \%$ level; ** statistical significance at the $5 \%$ level; * statistical significance at the $10 \%$ level. 3 . The estimates include time dummy variables, but not shown. 
Table 8: Chow Test - Determinants of Debt - Pecking Order Theory - Model II

\begin{tabular}{|c|c|c|c|}
\hline & Service SMEs versus Large Service Firms & Service SMEs versus Other SMEs & Service SMEs versus Other Large Firmss \\
\hline \multicolumn{4}{|l|}{ Independent variables } \\
\hline \multirow[t]{2}{*}{$\mathrm{CF}_{\mathrm{i}, \mathrm{t}}$} & $14.49 * * *$ & $16.71 * * *$ & $22.79 * * *$ \\
\hline & $(0.0000)$ & $(0.0000)$ & $(0.0000)$ \\
\hline \multirow[t]{2}{*}{$\mathrm{AGE}_{\mathrm{i}, \mathrm{t}}$} & $13.13 * * *$ & $17.05 * * *$ & $20.14 * * *$ \\
\hline & $(0.0000)$ & $(0.0000)$ & $(0.0000)$ \\
\hline \multirow[t]{2}{*}{$\mathrm{HGOLCF}_{\mathrm{i}, \mathrm{t}}$} & $12.27 * * *$ & $12.83 * * *$ & $18.66 * * *$ \\
\hline & $(0.0000)$ & $(0.0000)$ & $(0.0000)$ \\
\hline \multirow[t]{2}{*}{$\mathrm{LGOHCF}_{\mathrm{i}, \mathrm{t}}$} & $15.90 * * *$ & $15.55 * * *$ & $16.14 * * *$ \\
\hline & $(0.0000)$ & $(0.0000)$ & $(0.0000)$ \\
\hline \multirow[t]{2}{*}{ Global Difference } & $14.86 * * *$ & $16.82 * * *$ & $20.44 * * *$ \\
\hline & $(0.0000)$ & $(0.0000)$ & $(0.0000)$ \\
\hline
\end{tabular}

Notes: 1. Probabilities in parenthesis. 2. *** statistical significance at the $1 \%$ level; $* *$ statistical significance at the $5 \%$ level; * statistical significance at the $10 \%$ level.

Table 9: Survival Analysis - Trade-Off Theory Model

\begin{tabular}{|c|c|c|c|c|}
\hline \multirow[b]{3}{*}{ Independent variables } & \multicolumn{4}{|c|}{ Dependent Variable: $\operatorname{Pr}\left(\delta_{\mathrm{i}, \mathrm{t}}=1\right)$} \\
\hline & Service SMEs & Large Service Firms & Other SMEs & Other Large Firms \\
\hline & & & & \\
\hline \multirow[t]{2}{*}{$\mathrm{PROF}_{\mathrm{i}, \mathrm{t}}$} & $0.63412 * * *$ & $0.27381 * * *$ & $0.45217 * * *$ & $0.08712 *$ \\
\hline & $(0.09019)$ & $(0.51629)$ & $(0.07165)$ & $(0.04498)$ \\
\hline \multirow{2}{*}{ SIZE $_{i, t}$} & $0.04944 * * *$ & $0.03982 * *$ & $0.11919 * * *$ & $0.10928 * *$ \\
\hline & $(0.01506)$ & $(0.01875)$ & $(0.03621)$ & $(0.05418)$ \\
\hline \multirow[t]{2}{*}{ TANG $_{\mathrm{i}, \mathrm{t}}$} & 0.05512 & 0.05331 & $0.36171 * * *$ & $0.30442 * * *$ \\
\hline & $(0.10823)$ & $(0.11008)$ & $(0.08990)$ & $(0.07680)$ \\
\hline \multirow[t]{2}{*}{$\mathrm{GO}_{\mathrm{i}, \mathrm{t}}$} & $0.06511 *$ & $0.08918 * *$ & 0.04154 & $0.09412 * *$ \\
\hline & $(0.03450)$ & $(0.04411)$ & $(0.07616)$ & $(0.04657)$ \\
\hline \multirow[t]{2}{*}{ NDTS $_{i, t}$} & 0.00616 & 0.01828 & -0.00978 & 0.01450 \\
\hline & $(0.01981)$ & $(0.02554)$ & $(0.02003)$ & $(0.03811)$ \\
\hline \multirow[t]{2}{*}{$\mathrm{ETR}_{\mathrm{i}, \mathrm{t}}$} & -0.01848 & -0.01125 & -0.02172 & -0.03008 \\
\hline & $(0.02901)$ & $(0.03879)$ & $(0.05142)$ & $(0.06169)$ \\
\hline \multirow[t]{2}{*}{$\mathrm{EVOL}_{\mathrm{i}, \mathrm{t}}$} & $-0.06172 * * *$ & $-0.04132 * *$ & $-0.02812 * * *$ & -0.01181 \\
\hline & (0.01829) & $(0.02014)$ & $(0.01122)$ & $(0.01165)$ \\
\hline \multirow[t]{2}{*}{ CONS } & 0.01313 & 0.00987 & 0.01242 & 0.01451 \\
\hline & $(0.02182)$ & $(0.01761)$ & (0.02026) & $(0.02880)$ \\
\hline Pseudo $\mathrm{R}^{2}$ & 0.34152 & 0.32911 & 0.38918 & 0.36631 \\
\hline Log Likelihood & -115.95 & -113.40 & 109.01 & 106.77 \\
\hline Firms & 610 & 126 & 679 & 132 \\
\hline Observations & 3933 & 851 & 4348 & 872 \\
\hline
\end{tabular}

Notes: 1. Standard deviations in parenthesis. 2. *** statistical significance at the $1 \%$ level; ** statistical significance at the $5 \%$ level; $*$ statistical significance at the $10 \%$ level. 3 . The estimates include time dummy variables, but not shown. 
Table 10: Trade of Theory Model - GMM System (1998) Estimator

\begin{tabular}{|c|c|c|c|c|}
\hline \multirow{3}{*}{ Independent variables } & \multicolumn{4}{|c|}{ Dependent Variable: $\mathrm{D}_{\mathrm{i}, \mathrm{t}}$} \\
\hline & Service SMEs & Large SMEs & Other SMEs & Other Large Firms \\
\hline & & & & \\
\hline \multirow{2}{*}{$\mathrm{D}_{\mathrm{i}, \mathrm{t}-1}$} & $0.78120 * * *$ & $0.59192 * * *$ & $0.62931 * * *$ & $0.47716 * * *$ \\
\hline & $(0.06718)$ & $(0.05416)$ & $(0.05844)$ & $(0.04990)$ \\
\hline \multirow{2}{*}{$\mathrm{PROF}_{\mathrm{i}, \mathrm{t}}$} & $-0.91432 * * *$ & $-0.57818 * * *$ & $-0.62461 * * *$ & $-0.43129 * * *$ \\
\hline & $(0.09018)$ & $(0.06712)$ & $(0.08172)$ & $(0.05449)$ \\
\hline \multirow[t]{2}{*}{$\mathrm{SIZE}_{\mathrm{i}, \mathrm{t}}$} & $0.08198 * * *$ & 0.02911 & $0.04891 * *$ & 0.01122 \\
\hline & $(0.02923)$ & $(0.02844)$ & $(0.01550)$ & $(0.01874)$ \\
\hline \multirow{2}{*}{ TANG $_{i, t}$} & $0.39525 * * *$ & $0.21456^{* *}$ & $0.23081 * * *$ & $0.12911 * *$ \\
\hline & $(0.08917)$ & $(0.10604)$ & $(0.07189)$ & $(0.06357)$ \\
\hline \multirow[t]{2}{*}{$\mathrm{GO}_{\mathrm{i}, \mathrm{t}}$} & -0.01516 & 0.01781 & $-0.03481 * *$ & $-0.07746 * * *$ \\
\hline & $(0.07817)$ & $(0.06992)$ & $(0.01138)$ & $(0.02407)$ \\
\hline \multirow[t]{2}{*}{ NDTS $_{i, t}$} & 0.03424 & $-0.17821 * *$ & $-0.26931 * * *$ & $-0.37844 * * *$ \\
\hline & $(0.10889)$ & $(0.08615)$ & $(0.08918)$ & $(0.11423)$ \\
\hline \multirow[t]{2}{*}{$\mathrm{ETR}_{\mathrm{i}, \mathrm{t}}$} & 0.00771 & $0.06171 * *$ & -0.01056 & $0.08441 * * *$ \\
\hline & $(0.02668)$ & $(0.03012)$ & $(0.03135)$ & $(0.02435)$ \\
\hline \multirow[t]{2}{*}{$\mathrm{EVOL}_{\mathrm{i}, \mathrm{t}}$} & 0.00982 & 0.00574 & $-0.01818 * * *$ & $-0.02551 * * *$ \\
\hline & $(0.01223)$ & $(0.00913)$ & $(0.00457)$ & $(0.00511)$ \\
\hline \multirow[t]{2}{*}{$\lambda_{\mathrm{i}, \mathrm{t}}$} & $-15.6741 * * *$ & $-13.0071 * * *$ & $-16.9944 * * *$ & $-17.6131 * * *$ \\
\hline & $(3.1029)$ & $(2.87104)$ & $(3.2281)$ & $(3.6178)$ \\
\hline \multirow[t]{2}{*}{ CONS } & $0.06712 * *$ & $0.04123 *$ & 0.02371 & 0.01806 \\
\hline & $(0.03370)$ & $(0.02277)$ & $(0.03445)$ & $(0.02878)$ \\
\hline $\mathrm{F}(\mathrm{N}(0,1))$ & $56.90 * * *$ & $60.19 * * *$ & $64.59 * * *$ & $69.07 * * *$ \\
\hline Hansen $(\mathrm{N}(0,1))$ & 56.10 & 51.34 & 61.90 & 57.01 \\
\hline $\mathrm{m}_{1}(\mathrm{~N}(0,1))$ & $-5.87 * * *$ & $-6.07 * * *$ & $-5.61 * * *$ & $-5.94 * * *$ \\
\hline $\mathrm{m}_{2}(\mathrm{~N}(0,1))$ & 0.23 & 0.17 & 0.25 & 0.12 \\
\hline Firms & 534 & 116 & 567 & 113 \\
\hline Observations & 3097 & 685 & 3258 & 656 \\
\hline
\end{tabular}

Notes: 1. Standard deviations in parenthesis. 2. *** statistical significance at the $1 \%$ level; ** statistical significance at the 5\% level; * statistical significance at the $10 \%$ level. 3 . The estimates include time dummy variables, but not shown.

Table 11: Chow Test - Trade - Off Theory Model

Independent variables

\begin{tabular}{|c|c|c|c|}
\hline \multirow[t]{2}{*}{$D_{i, t-1}$} & $12.10 * * *$ & $10.96 * * *$ & $15.27 * * *$ \\
\hline & $(0.0000)$ & $(0.0000)$ & $(0.0000)$ \\
\hline \multirow[t]{2}{*}{$\mathrm{PROF}_{\mathrm{i}, \mathrm{t}}$} & $11.68 * * *$ & $9.87 * * *$ & $16.02 * * *$ \\
\hline & $(0.0000)$ & $(0.0000)$ & $(0.0000)$ \\
\hline \multirow[t]{2}{*}{ SIZE $_{i, t}$} & $16.84 * * *$ & $13.22 * * *$ & $17.14 * * *$ \\
\hline & $(0.0000)$ & $(0.0000)$ & $(0.0000)$ \\
\hline \multirow[t]{2}{*}{$\mathrm{TANG}_{\mathrm{i}, \mathrm{t}}$} & $8.35 * * *$ & $7.91 * * *$ & $9.82 * * *$ \\
\hline & $(0.0000)$ & $(0.0000)$ & $(0.0000)$ \\
\hline \multirow[t]{2}{*}{$\mathrm{GO}_{\mathrm{i}, \mathrm{t}}$} & 0.89 & $8.10 * * *$ & $15.18 * * *$ \\
\hline & $(0.798)$ & $(0.0000)$ & $(0.0000)$ \\
\hline \multirow[t]{2}{*}{ NDTS $_{i, t}$} & $9.33 * * *$ & $11.44 * * *$ & $14.01 * * *$ \\
\hline & $(0.0000)$ & $(0.0000)$ & $(0.0000)$ \\
\hline \multirow[t]{2}{*}{ ETR $_{i, t}$} & $10.41 * * *$ & 1.21 & $11.99 * * *$ \\
\hline & $(0.0000)$ & $(0.616)$ & $(0.0000)$ \\
\hline \multirow[t]{2}{*}{ EVOL $_{\mathrm{i}, \mathrm{t}}$} & 0.61 & $11.77 * * *$ & $13.33 * * *$ \\
\hline & $(0.884)$ & $(0.0000)$ & $(0.0000)$ \\
\hline \multirow[t]{2}{*}{ al Difference } & $11.51 * * *$ & $12.33 * * *$ & $14.92 * * *$ \\
\hline & $(0.0000)$ & $(0.0000)$ & $(0.0000)$ \\
\hline
\end{tabular}

Notes: 1. Probabilities in parenthesis. $2 .{ }^{* * *}$ statistical significance at the $1 \%$ level; $* *$ statistical significance at the $5 \%$ level; * statistical significance at the $10 \%$ level. 